vailable online at website : http://e-journal.adpgmiindonesia.com/index.php/jmie

JMIE: Journal of Madrasah Ibtidaiyah Education, 2(2), 2018, 208-218

\title{
THE INFLUENCE OF MONOPOLY GAME TECHNIQUE ON MATHEMATICAL REASONING OF STUDENTS CLASS V OF ELEMENTARY SCHOOL OR ISLAMIC ELEMENTARY SCHOOL IN MATERIAL BUILD SPACE VOLUME
}

\author{
Khalimi, Fery Muhamad Firdaus, Rihlah Fauziah \\ UIN Syarif Hidayatullah Jakarta \\ Email: khalimi@,uinjkt.ac.id, fery.firdaus@uinjkt.ac.id, \\ rihlah.fauziah14@mhs.uinikt.ac.id
}

Naskah diterima : 20 September 2018, direvisi : 25 September 2018, disetujui : 17 Oktober 2018

\begin{abstract}
This study aims to analyze the influence of monopoly game technique on mathematical reasoning of students of grade $\mathrm{V}$ of $\mathrm{MI} / \mathrm{SD}$ in material build space volume. This research was conducted in MI Salafiyah Syafi'iyyah class V second semester of academic year 2017/2018 material volume of cube and beam building space. Monopoly game technique is a monopoly game that is modified as a tool for learning process with the addition of various questions in the game technique. The method used in this research is quasi experiment with research design of The Nonequivalent Pretest-Posttest Control Group, which involves a sample of 32 students of experimental class and 31 students of control class. Based on the posttest result of mathematical reasoning the students who were taught using monopoly game techniques were higher than the uneducated students using the monopoly game technique. This can be seen from the mean value of posttest of students' mathematical reasoning which is taught by monopoly game technique is equal to 77,72 and mean value of posttest of mathematical reasoning of student which not taught by monopoly game technique is equal to 70,32. From Mann Whitney $\mathrm{U}$ test results obtained results of 0.029 at significance level of $0.05(0,000 \leq 0,05)$. Then from the calculation of effect size, it is known that the effect size of this research is $d=0,572$, so monopoly game technique has influence in medium category. Thus it can be concluded that the use of monopoly game techniques have an effect on mathematical reasoning of grade V students in MI Salafiyah Syafi'iyyah in the material volume of the cube and beam building space.
\end{abstract}

Keywords: Monopoly Game Technique, Learning Volume Build Cube Room and Beam, Student Mathematical Reasoning

Pengutipan: Khalimi, Fery Muhamad Firdaus, Rihlah Fauziah. (2018). The Influence of Monopoly Game Technique on Mathematical Reasoning of Students Class V of Elementary School or Islamic Elementary School in Material Build Space Volume. JMIE: Journal of Madrasah Ibtidaiyah Education, 2(2), 2018, 208-218. jmie.v2i2.74.

Permalink/DOI: http://dx.doi.org/ 10.32934/jmie.v2i2.74 


\section{INTRODUCTION}

Learning is a basic process of education, because learning is always there in the educational process (Abidin, 2015:17). Mathematical learning is a way of thinking and reasoning that is used to solve various types of problems in everyday life, science, government, and industry. In school math learning is one of the most important lessons taught in every level of education, especially in MI/SD. From class I to class VI mathematics is a subject that must exist in every semester. This is because mathematics has a very important role in the mastery of science and technology.

In the process of learning mathematics reasoning activities are not separated in it. National Departmen of Education (Depdiknas) (Burais and others, 2016:78) states that "Mathematical material and mathematical reasoning are two inseparable matters, that is, mathematical matter understood through reasoning and reasoning understood and trained through learning mathematical material". In addition to that in The Policy of Minister of National Education (Permendiknas) Number 22 of 2006 on the competency standard of graduates the purpose of learning mathematics is to use reasoning on the pattern and nature, perform mathematical manipulation in making generalizations, compile evidence, or explain mathematical ideas and questions and have an appreciation of the usefulness of mathematics in life, has a curiosity, attention, and interest in learning mathematics, as well as a tenacious attitude and confidence in problem solving (Sulistyani \& Retnawati, 2015:1). Thus, teachers must be able to form students to be able to develop the ability of reasoning so that students are able to construct knowledge in the field of mathematics and other fields of science for life in the future.

In November 2017 researchers conducted observations at MI Salafiyah Syafi'iyyah Depok City. Researchers conducted observations in class V on mathematics subjects. When teachers are teaching without using media, props or games in their learning process, researchers see there are some students who do not listen to the lessons conveyed by the teacher. They look busy with their own activities, some play erasers, draw a book, and doodle that should not be done while the lesson is in progress. Despite being reprimanded by teachers who teach but after being reprimanded they do it again without the teacher's knowledge. As a result, when given the task to solve individual problems some students are not able to do math problems correctly. Some of them do not do it, and some students ask for help from friends who understand better. 
In addition to observation, researchers also conducted interviews on the teacher concerned is a teacher of mathematics class V MI Salafiyah Syafi'iyyah. From the interview result can be concluded that each student has different character and of course different handling also. Along with the development of the times, methods or ways of teaching different classes each year. In 2010 and above the teacher tried to change his teaching method by using problem solving method, using the practices, and using media, props, and games. By using this method the average student learning outcomes increase, from the average score of student learning outcomes of 5 to 7 in the range of $1-10$.

Based on the observations and interviews to develop mathematical reasoning, the students should be able to modify the class well in order to create an active, fun, and meaningful lesson for the students. One of the teachers can use the game in learning that aims to make students feel happy while learning. Basically childhood is a period of play, therefore the game greatly influence and support the development of the child's personality both the mental development and emotional stability, the development of self-insight, increased concentration, social communications, and train children's creativity (Hanifah \&Julia, 2014:472).

Monopoly game is a children's game on board that is very famous in the world. Most children already know the game of monopoly and how to play it. In learning, monopoly game techniques can be used as a learning tool that can support the learning process for the creation of learning objectives well. In monopoly game techniques are included various kinds of questions that can train students' mathematical reasoning. Besides monopoly games have many advantages such as the process of making a simple, does not require a large room to store, maintenance and maintenance is relatively easy, easy to carry and move, this game has many components so as to train the students' accuracy and patience, made in full color so it is not boring, students can feel the sense of fun and curiosity, and the monopoly is easy to operate.

Based on the above matters, the researcher is interested in conducting a research entitled "The Influence of Monopoly Game Technique on Mathematical Reasoning of Students Class V of Elementary School or Islamic Elementary School in Material Build Space Volume". 


\section{RESEARCH METHODS}

\section{Research Approach}

The research approach used in this research is quantitative approach. The kuntitatif approach is used because in this study aims to calculate the sample of the population which is then analyzed by using statistics.

\section{Research Methods and Design}

The research design used was quasi experiment. Quasi experiments are used because in this study can not control the overall variables from outside that influence it. This quasi-experimental research design uses The Nonequivalent Pretest-Posttest Control Group Design research.

\section{Population and Sample}

The population used is grade V students MI Salafiyah Syafi'iyyah registered in 2017/2018. The number of students of grade V MI Salafiyah Syafi'iyyah as many as 63 students are divided into 2 classes. VA class as experimental class is class which is taught by using monopoly game technique and class VB as control class that is class which is not taught by using monopoly game technique. In this research, sampling technique is done by using sampling jenuh. Sampling jenuh is a technique of determining the sample by making all members of the population used as a sample (Lestari \& Yudhanegara, 2015:111). So the researcher took all the samples from the population of each class V.

\section{RESULT AND DISCUSSION}

In this study, researchers create their own monopoly game board which serve as a tool in the process of learning mathematics. The materials used to make a monopoly game are the ingredients in the environment, such as cardboard, HVS paper, paper glue, ruler, pencil, eraser, scissors, markers, and etc. In addition, researchers make various kinds of questions to train students' mathematical reasoning. Then to play the monopoly game requires monopoly game equipment such as, pawns to represent players, 2 dice stones together with the whiskers. a board game with plots (start, question-free, prison, jail, wake-up name, train station, bus station, water and electricity company, general funds, and opportunity), monopoly money, 32 green houses and 12 hotels in red, public funds cards and occasions, building property rights cards with information on price complexes, and questions about building cube and beam material space. 
The monopoly game techniques are as follows: (1) This game can be played from two to six people. (2) Each player is given the same amount of money. (3) The first player must throw a pair of dice and move with the number of dice out. (4) Players can buy land plots that have no owners and can build homes and hotels in the next round. (5) If there are other players who stop at home or hotel, then he hars pay the rent in accordance with the explanations contained in the card. (6) The player who has the most amount of money is the winner (Kristiani, 2014:106).

This monopoly game can be used in the learning process as a learning tool. Because the monopoly game is easy to operate and has the appeal of students to play while learning. Monopoly game made by researcher in this research as follows:

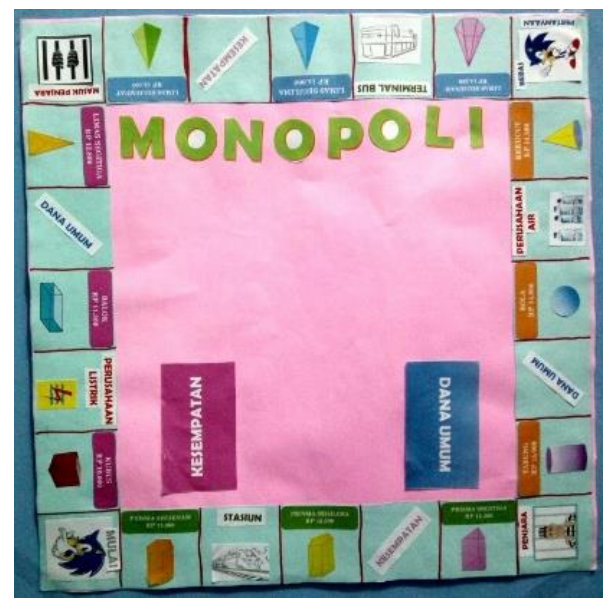

Figure 1. Monopoly Board Game

Researchers used a technique to measure the monopoly game of mathematical reasoning students class V MI Salafiyah Syafi'iyyah. Researchers conducted the learning process as many as seven times the meeting. In the first meeting the researcher gave pretest to the experimental class and control class. Then the researchers conducted five meetings in each class to be given treatment that is a different learning process. Then at the last meeting the researcher gives posttest to each class to measure the student's mathematical reasoning.

Here is an atmosphere of learning activities in the experimental class and control class. 

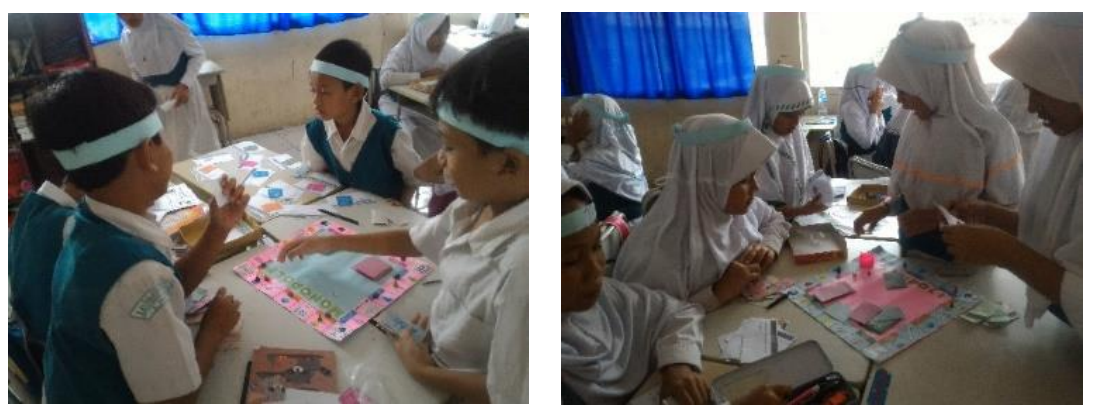

Figure 2. Experimental Classroom Learning Atmosphere

Figure 2 shows the students of the experimental class playing a monopoly game in the volume material of the cube and beam space. In the first lesson students find it difficult to play this monopoly game, because the game technique is made slightly different from the monopoly game in general. However, in the next lesson, the students are accustomed and happy when playing this monopoly. They are active in the game and active also in answering questions provided. So when given the matter of individuals they can do it quickly and correctly.
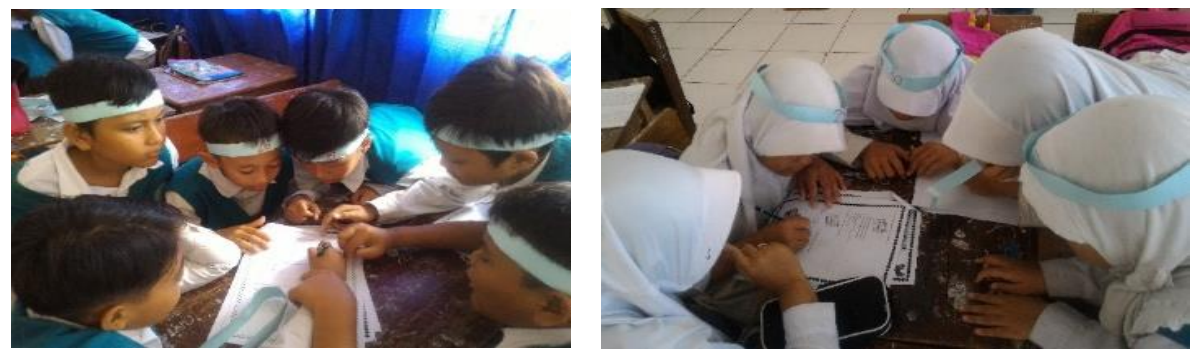

Figure 3. Control Classroom Learning Atmosphere

Figure 3 shows the grade students control is a discussion group working worksheet students. Members groups involved in the work worksheet students. However, only one person to be the scribe and only a few students are donated the answer while the other students just listen explanation of the student.

In this study found that monopoly game techniques have a positive impact on students' mathematical reasoning. It can be seen from posttest result of experiment class and control class that presented in table form as follows: 
Tabel 1. Comparison of Posttest Result of Student Mathematical Reasoning Experiment Class and Control Class

\begin{tabular}{lcc}
\hline \multirow{2}{*}{ Statistics } & \multicolumn{2}{c}{ Class } \\
\cline { 2 - 3 } & Experiment & Control \\
\hline Minimum $\left(\mathrm{X}_{\text {min }}\right)$ & 42 & 42 \\
Maksimum $\left(\mathrm{X}_{\text {maks }}\right)$ & 96 & 96 \\
Average $($ mean $)$ & 77,72 & 70,32 \\
Median $(\mathrm{Me})$ & 79,00 & 71,00 \\
Mode $($ Mo $)$ & 67 & 83 \\
Variance $\left(\mathrm{s}^{2}\right)$ & 161,241 & 221,092 \\
Standar Deviation $(\mathrm{s})$ & 12,698 & 14,869 \\
\hline \multicolumn{1}{c}{ Amount of Sample } & 32 & 31 \\
\hline
\end{tabular}

Based on Table 1 above it is known that the average experimental class is 77.72 and the control class is 70.32 , meaning that the students' mathematical reasoning is higher than the students' mathematical reasoning. It has also been proved by hypothesis testing that the test results of Mann Whitney $\mathrm{U}$ posttest experimental class and control class got a significance of 0.000 . According to the criterion $0.000 \leq 0.05$, it is concluded that $\mathrm{H}_{0}$ is rejected and $\mathrm{H}_{\mathrm{a}}$ accepted, it means that there is a significant difference between posttest result of experiment class and control class. In addition, in this study also performed the calculation of effect test (Effect Size) on the results of experimental class posttest and control class. From the results of the test results obtained $d=0,572$ which means that in the interpretation table Cohen's values are at a moderate level of influence, meaning that monopoly game techniques have a good influence on mathematical reasoning of grade V students in MI Salafiyah Syafi'iyyah.

\section{DISCUSSION}

Based on the research that has been done in class V MI Salafiyah Syafi'iyyah in the material volume of wake up space found that the mathematical tuning of students experimental class that taught monopoly game techniques the average grade grade increased. It can be seen from the posttest result of experiment class average value is 77,72 and control class is 70,32 , meaning that the students' experimental mathematical reasoning is higher than mathematical reasoning of control class students. 
'The students' mathematical reasoning used in this study is similar to Gardner's, et al. (Lestari \& Yudhanegara, 2015:82) opinion, which reveals that mathematical reasoning is "the ability to analyze, generalize, synthesize/integrate, provide the right reasons and solve non-routine problems". The mathematical reasoning indicator used in this study refers to Sumarmo's opinion, as follows: (1) Interesting logical conclusion. (2) Explain the model, the fact, the properties, and the relationship. (3) Estimate the answer and the solution. (4) Use patterns and relationship to analyze the situation or create an analogy and generalization. (5) Develop and test konjektur. (6) Make counter example (cons example). (7) Follow the rules of inference and check out the validity of argument. (8) Prepare argument invalid. (9) Prepare proof direct, indirect, and use the induction of mathematics (Lestari \& Yudhanegara, 2015: 82).

In this study clearly seen from the analysis of the answers reasoning mathematical students that class experimental and grade control can reasoning in answered questions mathematics. However, there is the difference of results posttest class experimental and grade control can be concluded that the reasoning mathematical grade students experiment higher than the reasoning mathematical grade students control. Because in the process of learning class experiments taught using techniques monopoly game while the class control taught not using techniques monopoly game.

The game of monopoly it self is a very famous children's game on board in the world (Kristiani, 2014:105). Monopoly games are used in this study because the monopoly game has many advantages, including: (1) The making process is simple. (2) Does not require a large room to store. (3) Treatment and maintenance is relatively easy. (4) Easy to carry and move. (5) This game has many components so it can train the students' thoroughness and patience. (6) Made with color so not boring. (7) Students can feel a sense of fun and curiosity. (8) Easy to operate (Susanto dkk, 2012: 3).

The many advantages of the above monopoly game make the researcher interested to use monopoly game technique in this research. In the study, researchers found that using monopoly game techniques gave effect in the medium category to students' mathematical reasoning. This is evident from the results of the determination of the effect of the effect (Effect Size) that is equal to $d=572$. This study is in accordance with the opinion of Depdiknas (Burais dkk, 2016:78) said that "Mathematical material and reasoning mathematics are two inseparable things, namely mathematical material is understood through reasoning and reasoning understood and trained through learning mathematics material ". Given the monopoly game technique in the experimental class, mathematical reasoning of experimental class students is 
trained step by step through the various questions asked. This causes students to practice their reasoning skills while playing so that students do not feel bored while learning math.

In MI Salafiyah Syafi'iyyah the age of grade V children is ranged between 10 or 11 years. This age is the age of transition from children to adolescence, usually children tend to learn while playing and have a high curiosity. Therefore, researchers used game techniques in this study. This is in line with the opinion of Suyatno (Hidayat, Muhajir, 2015:220) that the game in education is a vehicle for students to learn how to learn for the benefit of students. In addition to playing according to Anggani (Sudono, 2006:1) is "an activity conducted with or without using tools that produce understanding or provide information, give pleasure and develop imagination in children". In this study, researchers found that there is a difference in the spirit of learning between the experimental class and the control class. When the process of learning in the experimental class, researchers provide monopoly game techniques, so students become eager to learn. They are active to answer the questions given and actively ask when less understood. The facial expression of joy radiated on their faces, because the learning process with monopoly game techniques is different from the process of learning in general.

In line with Piaget's (Yaumi, 2013:139) opinion, at the age of 7 - 11 years the child is in concrete operational stage. Cognitive development at this stage is that children begin to reason logically to recognize concrete events and clarify objects to different settings. The ability that appears in this phase is the ability in the thought process to operate logic rules, although still related to concrete objects. This is in accordance with the conditions found by researchers, where students can reason logically based on the material being taught. Students learn the material of the volume of building the cube space and the beam by using the monopoly game technique, from the student monopoly game technique can reason through the questions given.

Based on the research and results of the data above, it can be concluded that there is influence the use of monopoly game techniques to mathematical reasoning of students class V MI Salafiyah Syafi'iyyah in the material volume of cube and beam building space. However, in this study researchers realized that this study has some things that have not been perfect. 


\section{CONCLUSION}

Based on the research that has been done, it can be concluded that the mathematical reasoning of experimental class students using monopoly game techniques is higher than the mathematical reasoning of control class students who do not use monopoly game techniques. This can be seen from the average posttest of the experimental class of 77.72 and the control class of 70.32. In addition, the results of hypothesis testing using Mann Whitney $U$ test stated that the posttest result of the experimental class and control class got a significance of 0.000 . In accordance with 0,000 $\leq 0,05$, it is concluded that $\mathrm{H}_{0}$ is rejected and $\mathrm{H}_{\mathrm{a}}$ is accepted. Then based on the effect size test obtained $d=0,572$ which means in the interpretation table Cohen's value is at the level of influence is. So it can be concluded that the monopoly game technique has influence in the category of moderate to mathematical reasoning of class $\mathrm{V}$ students semseter II academic year 2017/2018 at MI Salafiyah Syafi'iyyah in the material of the volume of cube and beam building space.

The implications of this research are: First, the use of monopoly game technique in the material of cube and beam building volume can be applied to learning mathematics $\mathrm{MI} / \mathrm{SD}$ in improving mathematical reasoning of class $\mathrm{V}$ students. Secondly, the result of this research as input of teacher and school to increase mathematical reasoning students. Teachers can use this monopoly game technique in proper learning to be applied in the learning process especially on the material of building up the cube and block space which can improve students' mathematical reasoning. Schools can apply and develop monopoly game techniques on materials and other subjects so as to enhance student motivation and achievement, so that student reasoning can increase.

\section{REFERENCES}

Abidin, Zainal. Intuisi Dalam Pembelajaran Matematika. Jakarta: Lentera Ilmu Cendikia, 2015.

Burais, Listika dkk. Peningkatan Kemampuan Penalaran Matematis Siswa Melalui Model Discovery Learning. Jurnal Didaktik Matematika. Vol. 3, No. 1, 2016.

Sulistyani, Niluh dan Heri Retnawati. Pengembangan Perangkat Pembelajaran Bangun Ruang Di SMP Dengan Pendekatan Problem-Based Learning. Jurnal Riset Pendidikan Matematika. Vol. 2, No. 2, 2015. 
Hanifah, Nurdinah dan Julia. Prosding Seminar Nasional Pendidikan Dasar; Membedah Anatomi Kurikulum 2013 Untuk. Membangun Masa Depan Pendidikan Yang Lebih Baik. Sumedang: UPI Sumedang Press, 2014.

Kristiani, Dian. Ensiklopedia Negeriku; Permainan Tradisional. Jakarta, PT Bhuana Ilmu Populer, 2014.

Lestari, Karunia Eka dan Mokhammad Ridwan Yudhanegara. Penelitian Pendidikan Matematika. Bandung: PT Refika Aditama, 2015.

Susanto, Arif dkk. Permainan Monopoli Sebagai Media Pembelajaran Sub Materi Sel Pada Siswa SMA Kelas XI IPA. Jurnal Edukasi. Vol. 1, No. 1, 2012.

Hidayat, Atma dan Muhajir. Pengembangan Permainan Monopoli Sebagai Media Pembelajaran Batik Kelas V SD Siti Aminah Surabaya. Jurnal Pendidikan Seni Rupa. Vol. 3, No. $2,2015$.

Sudono, Anggani. Sumber Belajar dan Alat Permainan; Untuk Pendidikan Usia Dini. Jakarta, PT Grasindo, cet. 5, 2006.

Yaumi, Muhammad. Prinsip-Prinsip Desain Pembelajaran. Jakarta: Prenadamedia Group, 2013. 